\title{
Delftia acidovorans pneumonia with lung cavities formation
}

\section{Neumonia por Delftia acidovorans con formación de cavidades pulmonares}

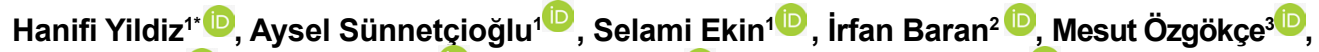 \\ Selvi Aşker ${ }^{1}$, İbrahim Üney ${ }^{\circledR}$, Engin Turgut ${ }^{4}$ and Sümeyye Akyüz $^{5}$ \\ 1 Van Yuzuncu Yil University, Faculty of Medicine, Department of Chest Medicine, Tuşba/Van, Turkey., 2 Van \\ Yuzuncu Yil University, Faculty of Medicine, Department of Infectious Disease, Tuşba/Van, Turkey., 3 Van \\ Yuzuncu Yil University, Faculty of Medicine, Department of Radiology, Tuşba/Van, Turkey, 4 Van Yuzuncu \\ Yil University, Faculty of Medicine, Department of Internal Medicine, Tuşba/Van, Turkey, $\mathbf{5}$ Van Yuzuncu Yil \\ University, Faculty of Medicine, Medical Microbiology Department, Tuşba/Van, Turkey, \\ *yhanifi1980@gmail.com hanifiyildiz@yyu.edu.tr
}

\section{6}

\section{OPEN ACCESS}

Citation: Yildiz H, Sünnetçioğlu A, Ekin S, Baran Al, Özgökçe M, Aşker S, Üney I, Turgut E, Akyüz S. Delftia acidovorans pneumonia with lung cavities formation. Colomb Med (Cali). 2019; 50(3): 215-21. http:// dx.org/1025100/cm.v50i3.4025

Received: 05 Jul 2019

Revised: 17 Aug 2019

Accepted: 25 Sep 2019

\section{Keywords:}

Delftia acidovorans, gramnegative bacterial infections, immunocompromised host, bacterial pneumonia, respiratory tract infections, respiratory sounds, cough, Piperacillin, Piperacillin Tazobactam drug combination, multiple pulmonary nodules, lung diseases interstitial

Palabras clave:

Delftia acidovorans, bacterias aerobicas gram-negativas, huesped immunocomprometido, pneumonia por bacterias, infecciones del tracto respiratorio,sonidos respiratorios, tos, Piperacilina, combinación Piperacilina Tazobactam, nodulos pulmonares multiples, enfermedad pulmonar interstitial

\section{Abstract}

\section{Case Description:}

A 52-year-old female patient was admitted to our clinic with complaints of cough, sputum, fever and fatigue. The patient has been receiving immunosuppressive therapy for thrombocytopenic purpura for 5 years.

\section{Clinical Finding:}

Inspiratory crackles were heard on both hemithorax. Oxygen saturation measured with the pulse oximeter was $97 \%$. Chest X-ray showed diffuse reticular opacities that were more prominent in the upper zones of both lungs. WBC counts were 17,600 $\mathrm{mm} 3$ and Platelet counts were $29,000 \mathrm{~mm} 3$. Thorax CT showed that there were many thin-walled cavities and millimetric nodules accompanied by ground-glass infiltrates in the upper and middle lobes. Gram staining of bronchial fluid, taken by bronchoscopy, revealed Gram-negative bacilli and intense polymorphonuclear leukocytes. The bacteria were defined as Delftia acidovorans by BD Phoenix automated system.

\section{Treatment and outcomes:}

The patient was hospitalized with suspicion of opportunistic pulmonary infections and cavitary lung disease. After the empirical treatment of intravenous piperacillintazobactam and oral clarithromycin, her clinical and radiological findings significantly regressed, and she was discharged with outpatient follow-up.

\section{Clinical Relevance:}

This is the first example of cavitary pneumonia due to Delftia acidovorans in an immunocompromised patient. We would like to emphasize that Delftia pneumonia should be considered in the differential diagnosis of pulmonary cavitary involvement in such patients. 
Copyright: ( ) 2019. Universidad del Valle.

\section{(c) (i) $\Theta$}

Conflicts of interest:

The authors declare that there were no conflicts of interest for the writing of this article

\section{Resumen}

\section{Descripción del caso:}

Una mujer de 52 años llegó a la clínica con tos, esputo, fiebre y fatiga. El paciente estuvo recibiendo terapia inmunosupresora durante 5 años para el tratamiento de la púrpura trombocitopénica.

\section{Hallazgo clínico}

Se escucharon crepitaciones inspiratorias en ambos hemitórax. La saturación de oxígeno fue del $97 \%$. La radiografía de tórax mostró opacidades reticulares difusas que eran más prominentes en las zonas superiores de ambos pulmones. Los recuentos de leucocitos fueron de $17,600 \mathrm{~mm} 3$ y los recuentos de plaquetas fueron de $29,000 \mathrm{~mm} 3$. La TC de tórax mostró muchas cavidades de pared delgada y nódulos milimétricos acompañados de infiltrados vitrales en los lóbulos superior y medio. La tinción de Gram del líquido bronquial reveló bacilos gramnegativos y leucocitos polimorfonucleares. Las bacterias fueron identificadas como Delftia acidovorans.

\section{Tratamiento y resultados}

La paciente fue hospitalizado con una sospecha de infección oportunista pulmonar y enfermedad pulmonar cavitaria. Después del tratamiento empírico de piperacilinatazobactam intravenosa y claritromicina oral, los síntomas y signos retrocedieron significativamente, y fue dada de alta con seguimiento ambulatorio.

\section{Relevancia clínica}

Este es el primer registro de neumonía cavitaria causado por Delftia acidovorans en una paciente inmunocomprometida. Enfatizamos que la neumonía por Delftia debe considerarse en el diagnóstico diferencial de la afectación de la cavidad pulmonar en tales pacientes. 


\section{Introduction}

Although ITP was formerly used for idiopathic thrombocytopenic purpura, it is now used for pathologies that develop due to an immunological cause. But the autoantibodies are only diagnosed in $50-60 \%$ of patients ${ }^{1}$. The clinical process is usually longer in adults ${ }^{1}$. Treatment of ITP involves corticosteroids, intravenous immunoglobulins, anti-D, and rituximab (antiCD20) that are used differentially during the acute and persistent/chronic phase of the disease. Splenectomy is predominantly considered for refractory adult patients in the chronic phase ${ }^{1}$. Our patient also had a history of splenectomy due to refractory thrombocytopenia.

Delftia acidovorans is an anaerobic, oxidase positive and Gram-negative generally nonpathogenic bacillus that can be cultured in MacConkey agar ${ }^{2-5}$. There are few case reports in the literature that have been reported to cause infection in humans ${ }^{2,3}$. In accordance with some case reports Delftia acidovorans can cause infective endocarditis, ocular infections, otitis media, peritonitis, urinary tract infections, empyema, and nosocomial bacteremia, including central venous catheter-related bacteremia in immunocompromised individuals ${ }^{6}$. According to our investigation, here we present the first example of cavitary and interstitial pneumonia caused by Delftia acidovorans in a patient who received immunosuppressive treatment due to ITP.

\section{Case description}

A 52-year-old female patient was admitted to our outpatient clinic with complaints of chest pain, cough, sputum dyspnea, and weight loss, which was started three weeks ago. The patient with diabetes mellitus was under immunosuppressive therapy for five years due to drug-resistant ITP. Our patient also had a history of splenectomy due to refractory thrombocytopenia. In the last year, the patient's treatment was daily $50 \mathrm{mg}$ azathioprine and 4 mg methylprednisolone. On examination, the patient's temperature was $38^{\circ} \mathrm{C}$. The respiratory rate was $25 \mathrm{~min}$ and the pulse rate was 95 beats $/ \mathrm{min}$. In auscultation, the inspiratory crackles were heard on both hemithorax. WBC counts were $17,600 \mathrm{~mm}^{3}$ and platelet counts were 29,000 $\mathrm{mm}^{3}$. Oxygen saturation measured by the pulse oximeter was $97 \%$. Chest X-ray showed diffuse reticular opacities that were more prominent in the upper zones of both lungs (Fig. 1).

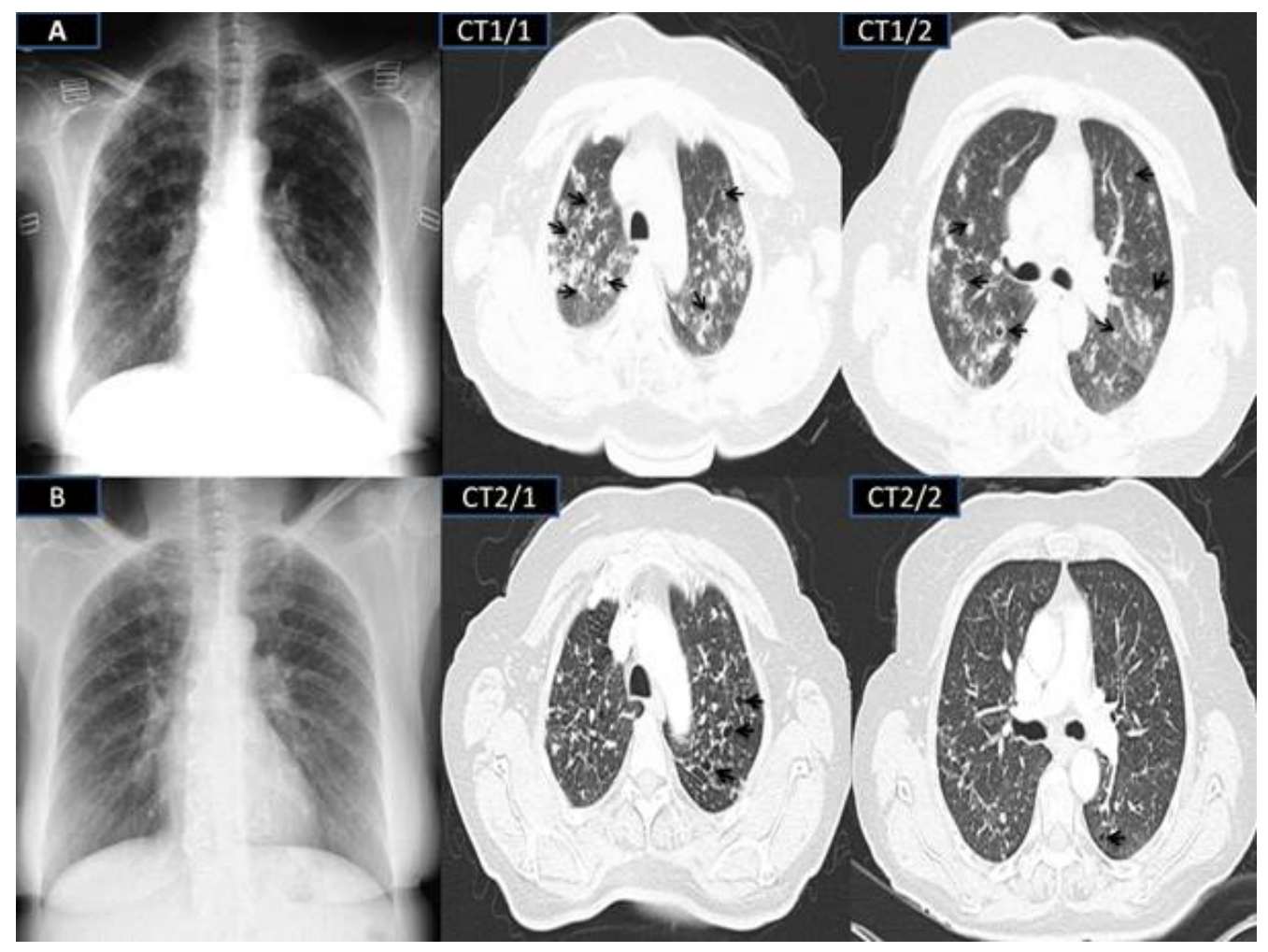

Figure 1. Radiography and thoracic CT images, taken at the time of admission and at 12th months of follow-up. A is showing the chest radiographic image, taken at admission, B is showing the radiographic image, taken at the 12th months of follow-up, CT1/1 and CT1/2 show the computed thoracic images, taken at the admission, and CT2/1 and CT2/2 are showing the computed thoracic images, taken at the 12th months of follow-up. Black arrows are indicating cavitary infiltrates. 
The patient was hospitalized with suspicions of opportunistic pulmonary infection and cavitary lung disease. Empirically, intravenous piperacillin-tazobactam $(3 \times 4.5 \mathrm{~g} /$ day $)$ and oral clarithromycin (2x500 mg/day) were started. Thorax CT revealed many thin-walled cavities and millimetric nodules accompanied by ground-glass infiltrates in the upper and middle lobes of both lungs (Fig. 1). Most of the nodules, which one of the largest has 17x12 mm in diameter, predominantly were located in the peripheral areas (Fig. 1). The disease which could develop cavities in the lung, such as tuberculosis, rheumatic lung diseases, vasculitis syndromes, and fungal infections were excluded by using acid-fast bacilli staining and Gram staining, serum and blood galactomannan levels, and vasculitis markers.

Gram staining of bronchial fluid, taken by bronchoscopy, revealed Gram-negative bacilli and intense polymorphonuclear leukocytes. The bronchial fluid sample obtained by bronchoscopy was inoculated in 5\% sheep blood and Eosin Methylene Blue (EMB) agar and then was cultured by semiquantitative culture method in the microbiology laboratory. The cultured sample was incubated for 48 hours at $37^{\circ} \mathrm{C}$ under aerobic conditions. After the incubation, the colonies, $>10^{5} \mathrm{CFU} / \mathrm{mL}$, which have the white central areas with gray edges and irregular borders, were observed in the blood agar. EMB agar revealed colonies that did not ferment lactose and had a clear appearance. In TSI medium, citrate and oxidase positive, mobile and Gramnegative bacilli, which couldn't ferment glucose, lactose, and sucrose, were detected. Delftia acidovorans were defined as by using the BD Phoenix automated microbiology system (BD Diagnostic Systems, Sparks, MD). Before the patient sample was inoculated into the automated system, there was no growth in the culture taken from the sample of the automated system to eliminate device-related contamination. Antibiotic susceptibility testing was also performed with the same system as previously performed ${ }^{7-9}$. The Phoenix ID broth was inoculated with bacterial colonies from a pure culture adjusted to a 0.5 to $0.6 \mathrm{McF}$ arland standard using a nephelometer. After having transferred $25 \mu \mathrm{L}$ of the ID suspension to the Phoenix AST broth, the suspension was poured into the ID side of the Phoenix panel. Once inoculated the panel was logged and loaded into the instrument, where kinetic measurements of colorimetric and fluorescent signals were collected every $20 \mathrm{~min}^{9}$. EUCAST 2017 criteria were used to evaluate the thresholds for antibiotic susceptibility, as in the study by Ranc et $a l^{10}$. Results were classified as sensitivity (S), moderate sensitivity (MS), and resistance (R) (Table 1).

Empirical treatment was continued for 21 days because the sensitivity was detected. After the treatment, the patient's clinical and radiological findings regressed significantly, and he was discharged with outpatient follow-up. At the 12th months of follow-up, thoracic CT taken for transient dyspnea revealed that pulmonary infiltrates were significantly reduced and only sequelae cavitary lesions could be observed (Fig. 1).

According to our investigation, this case is the first example of cavitary, and interstitial pneumonia caused by Delftia acidovorans in a patient with immunosuppression.

\section{Informed consent}

The written informed consent was obtained from the patient for the publication of this case report.

Table 1. Antibiotic susceptibility test result.

\begin{tabular}{lcc}
\hline Antibiotics & Sensitivity result & (MIC, $\boldsymbol{\mu g} / \mathbf{m L})$ \\
\hline Amikacin & Resistant & $>16$ \\
Aztreonam & Moderate-sensitive & 16 \\
Cefepime & Resistant & $>8$ \\
Ceftazidime & Sensitive & 1 \\
Ciprofloxacin & Resistant & $>2$ \\
Colistin & Resistant & $>4$ \\
Gentamicin & Resistant & $>4$ \\
Imipenem & Sensitive & 1 \\
Netilmicin & Resistant & $>4$ \\
Piperacillin & Sensitive & $\leq 4$ \\
Piperacillin/Tazobactam & Sensitive & $\leq 4 / 4$ \\
\hline
\end{tabular}

MIC: Minimum inhibitory concentration 


\section{Discussion}

A pulmonary cavity is defined as a gas-filled space in the lung and occurs by the accumulation of air into a nodule, mass or a region of consolidation ${ }^{11}$. A pulmonary cavity is the common finding of a wide variety of the pathological process which is affecting the lung. Since some diseases are more associated with the development of the pulmonary cavity the evaluation of the cavity helps to clinicians in the differential diagnosis ${ }^{12}$. According to the developmental periods, it is recommended to divide the cavities into two groups. Some cavities develop within the 12 weeks, while others require more than 12 weeks ${ }^{13}$. A rapidly developing cavity $(<12$ weeks) strongly suggests an infectious or acute cause. However, the cavities those had a more chronic or silent development (>12 weeks) support the presence of chronic infections, autoimmune conditions, or malignancy. Nevertheless, there may be a significant change in the temporal development of cavitary disease processes, depending on both the patient's immune status and comorbidities ${ }^{13}$. We suspected that the patient has an infection because the patient's complaints had started three weeks ago and she had been receiving immunosuppressive treatment for a long time. Moreover, the radiological findings also suggested the possibility of cavitary lung disease in addition to the suspicion about infectious diseases.

There are some reports of Delftia acidovorans that cause infection in humans $s^{2-5}$. However, in the literature, we could not find a study reported that Delftia acidovorans causes pulmonary cavitary disease. The vasculitis syndromes were not considered among the preliminary diagnoses since the markers of cavitary pulmonary vasculitis syndromes were negative.

The cavity development is more common in some disease such as tuberculosis and Klebsiella pneumoniae infections ${ }^{12}$. Additionally, some fungal infections may also cause cavity development in the lung ${ }^{12}$. However, in our patient's serial sputum microscopy the acidfast bacilli were not detected. Bronchoscopic fluid analysis has been reported to be useful when a specific infectious agent, such as fungal and tuberculosis infection, is suspected in immunocompromised patients ${ }^{14,15}$. Therefore, we also performed bronchoscopy for further analysis. The galactomannan antigen was found negative in serum and bronchoscopic fluid.

In a large-sample study using PCR for validity and comparing Biotyper (MALDI-TOF MS; matrix-assisted laser desorption ionization-time of flight mass spectrometry) and Phoenix methods, the urine-isolated bacteria was accurately identified $99.9 \%$ and $99.5 \%$ at the genus level, $99.1 \%$ and $98.5 \%$ at the species level ${ }^{7}$. Additionally, it has been demonstrated that the Phoenix automated microbiology systems can be used for in the majority of strains encountered in a university-based laboratory to evaluate the identification (ID) and antimicrobial susceptibility testing (AST) performances ${ }^{8}$. For this reason, we used this system to evaluate the identification (ID) and antimicrobial susceptibility test. By bronchial lavage fluid culture and automatized bacteria validation test Delftia acidovorans was detected.

Bilgin et al. ${ }^{2}$, reported a case of Delfia acidovorence pneumonia in a patient with neutropenia. However, in their case, there was no pulmonary cavitary involvement ${ }^{2}$. Taş et al. ${ }^{5}$, reported that they detect Delftia acidovorans in deep tracheal aspiration culture of a patient with chronic obstructive pulmonary disease. This patient with symptoms of lower respiratory tract infection died despite treatment ${ }^{5}$. The reported cases of Delfia infection consist mostly of patients with immunodeficiency ${ }^{2,16,17}$ However, there are also cases reported in immunocompetent patients ${ }^{3,5,18}$. Khan et al. ${ }^{3}$, reported a case of Delftia acidovorans bacteremia, in a four-year-old immunocompetent patient with pulmonary abscess. Patel et al..$^{14}$, reported a case of catheterrelated septic pulmonary embolism, caused by Delftia acidovorans in a 49-year-old woman with vertebral osteomyelitis. However, there was no cavitary pulmonary infiltrates in this patient CT images, and the CT scan revealed bilateral pulmonary nodules and pleural effusion. For an accurate diagnosis and treatment, the elimination of the contaminations is very important. Before examining the patient sample, we took a swab sample from the automated system in order to eliminate contamination. There was not a bacterial growth in the culture of this swab sample. Additionally, this organism couldn't be isolated from the culture of other patients. Moreover, the patient's clinical features, laboratory, and radiological findings indicated the presence of a pulmonary infection. These points supported the fact that this organism wasn't an environmental contaminant for our patient. 
In Latin America, Galles et al. ${ }^{19}$, examined a total of 176 unusual, non-facultative gramnegative bacteria, including four Delftia acidovorans isolates. In this multicenter study, there was poor in vitro efficacy with aminoglycosides. Although the information on Delftia acidovorans sensitivity is limited, Delftia acidovorans is generally known to be susceptible to broad-spectrum cephalosporins, piperacillin, aztreonam, carbapenems, quinolones, and trimethoprim-sulfamethoxazole ${ }^{19}$. Similarly, in our case, an effective response was obtained with piperacillin/tazobactam treatment (MIC $\leq 4 / 4 / \mathrm{g} / \mathrm{mL}$ ). Since Delftia acidovorans isolates are resistant to aminoglycosides, type determination is important for appropriate treatment ${ }^{20}$. Similarly, in our case, the bacterium was found to be resistant to aminoglycosides (MIC $<16 \mu \mathrm{g}$ / dL for amikacin).

According to our literature research, the case presented here will be the first example of pulmonary cavitary infiltrates due to Delftia acidovorans.

\section{Conclusion}

Delftia acidovorans pneumonia which can respond well to treatment should be considered, in immunocompromised patients with interstitial nodules and cavitary infiltrates.

\section{References}

1. Schulze H, Gaedicke G. Immune thrombocytopenia in children and adults: what's the same, what's different? Haematologica. 2011;96(12):1739-41. doi:10.3324/haematol.2011.055830

2. Bilgin H, Sarmis A, Tigen E, Soyletir G, Mulazimoglu L. Delftia acidovorans: A rare pathogen in immunocompetent and immunocompromised patients. Canadian J infect Dis Med Microbiol. 2015;26(5):277-9. doi: 10.1155/2015/973284

3. Khan S, Sistla S, Dhodapkar R, Parija SC. Fatal Delftia acidovorans infection in an immunocompetent patient with empyema. Asian Pacific J Trop Biomed. 2012;2(11):923-4. doi: 10.1016/S2221-1691(12)60254-8

4. Hagiya $\mathrm{H}$, Murase T, Sugiyama J, Kuroe $\mathrm{Y}$, Nojima H, Naito $\mathrm{H}$, et al. Delftia acidovorans bacteremia caused by bacterial translocation after organophosphorus poisoning in an immunocompetent adult patient. J Infect Chemoth. 2013;19(2):338-41. doi: 10.1007/s10156-012-0472-x

5. Tas T, Kucukbayrak A, Kocoglu E, Özsoy S, Bucak Ö, Tekelioglu ÜY, et al. Nosocomial pneumonia and bacteremia caused by Delftia acidovorans related to arterial catheter. Dicle Med J. 2012;39(3):3. doi: 10.5798/diclemedj.0921.2012.03.0180.

6. Weinstein RA, Stamm WE, Kramer L, Corey L. Pressure monitoring devices. Overlooked source of nosocomial infection. JAMA. 1976;236(8):936-8. doi: 10.1001/jama.236.8.936.

7. Yan Y, Meng S, Bian D, Quinn C, Li H, Stratton CW, et al. Comparative evaluation of Bruker Biotyper and BD Phoenix systems for identification of bacterial pathogens associated with urinary tract infections. J Clin Microbiol. 2011;49(11):3936-9. doi: 10.1128/JCM.05363-11.

8. Donay JL, Mathieu D, Fernandes P, Pregermain C, Bruel P, Wargnier A, et al. Evaluation of the automated phoenix system for potential routine use in the clinical microbiology laboratory. $\mathrm{J}$ Clin Microbiol. 2004;42(4):1542-6. doi: 10.1128/jcm.42.4.1542-1546.2004.

9. Fahr AM, Eigner U, Armbrust M, Caganic A, Dettori G, Chezzi C, et al. Two-center collaborative evaluation of the performance of the BD Phoenix automated microbiology system for identification and antimicrobial susceptibility testing of Enterococcus spp. and Staphylococcus spp. J Clin Microbiol. 2003;41(3):1135-42. doi: 10.1128/JCM.41.3.1135-1142.2003.

10. Ranc A, Dubourg G, Fournier PE, Raoult D, Fenollar F. Delftia tsuruhatensis, an emergent opportunistic healthcare-associated pathogen. Emerg Infect Dis. 2018;24(3):594-6. doi: 10.3201/eid2403.160939.

11. Tuddenham WJ. Glossary of terms for thoracic radiology: recommendations of the Nomenclature Committee of the Fleischner Society. AJR Am J Roentgenol. 1984;143(3):509-17. doi: 10.2214/ ajr.143.3.509. 
13. Gafoor K, Patel S, Girvin F, Gupta N, Naidich D, Machnicki S, et al. Cavitary lung diseases: a clinicalradiologic algorithmic approach. Chest. 2018;153(6):1443-65. doi: 10.1016/j.chest.2018.02.026.

14. Ramirez P, Valencia M, Torres A. Bronchoalveolar lavage to diagnose respiratory infections. Semin Respirat Crit Care Med. 2007;28(5):525-33. doi: 10.1055/s-2007-991524.

15. Sternberg RI, Baughman RP, Dohn MN, First MR. Utility of bronchoalveolar lavage in assessing pneumonia in immunosuppressed renal transplant recipients. Am J Med. 1993;95(4):358-64. doi: 10.1016/0002-9343(93)90303-7.

16. Kawamura I, Yagi T, Hatakeyama K, Ohkura T, Ohkusu K, Takahashi Y, et al. Recurrent vascular catheter-related bacteremia caused by Delftia acidovorans with different antimicrobial susceptibility profiles. J Infect Chemoth. 2011;17(1):111-3. doi: 10.1007/s10156-010-0089-x.

17. Lair MI, Bentolila S, Grenet D, Cahen P, Honderlick P. Oerskovia turbata and Comamonas acidovorans bacteremia in a patient with AIDS. European J Clin Microbiol Infect Dis. 1996;15(5):424-6. doi: 10.1007/ bf01690106.

18. Patel D, Iqbal AM, Mubarik A, Vassa N, Godil R, Saad M, et al. Delftia acidovorans: A rare cause of septic pulmonary embolism from catheter-related infection: Case report and literature review. Respirat Med Case Rep. 2019;27:100835. doi: 10.1016/j.rmcr.2019.100835.

19. Gales AC, Jones RN, Andrade SS, Sader HS. Antimicrobial susceptibility patterns of unusual nonfermentative gram-negative bacilli isolated from Latin America: report from the SENTRY Antimicrobial Surveillance Program (1997-2002). Mem Instituto Oswaldo Cruz. 2005;100(6):571-7. doi: 10.1590/s007402762005000600011.

20. LiPuma JJ, Currie BJ, Peacock SJ, Vandamme PAR. Burkholderia, Stenotrophomonas, Ralstonia, Cupriavidus, Pandoraea, Brevundimonas, Comamonas, Delftia, and Acidovorax. Manual of Clinical Microbiology, 10th Edition: American Society of Microbiology; 2011. doi: 10.1128/9781555817381.ch43 